\title{
Characterization of the distinct mechanism of agonist-induced canine platelet activation
}

\author{
Preeti K. Chaudhary, Soochong Kim* \\ Department of Veterinary Medicine, College of Veterinary Medicine, Chungbuk National University, Cheongju 28644, Korea
}

\begin{abstract}
Platelet activation has a major role in hemostasis and thrombosis. Various agonists including adenosine diphosphate (ADP) and thrombin interact with G protein-coupled receptors (GPCRs) which transduce signals through various G proteins. Recent studies have elucidated the role of GPCRs and their corresponding G proteins in the regulation of events involved in platelet activation. However, agonist-induced platelet activation in companion animals has not been elucidated. This study was designed to characterize the platelet response to various agonists in dog platelets. We found that 2-methylthio-ADP-induced dog platelet aggregation was blocked in the presence of either $\mathrm{P}_{2} \mathrm{Y}_{1}$ receptor antagonist MRS2179 or $\mathrm{P}_{2} \mathrm{Y}_{12}$ receptor antagonist AR-C69931MX, suggesting that co-activation of both the $\mathrm{P} 2 \mathrm{Y}_{1}$ and $\mathrm{P} 2 \mathrm{Y}_{12}$ receptors is required for ADP-induced platelet aggregation. Thrombin-induced dog platelet aggregation was inhibited in the presence of either AR-C69931MX or the PKC inhibitor GF109203X, suggesting that thrombin requires secreted ADP to induce platelet aggregation in dog platelets. In addition, thrombin-mediated Akt phosphorylation was inhibited in the presence of GF109203X or AR-C69931MX, indicating that thrombin causes $\mathrm{G}_{\mathrm{i}}$ stimulation through the $\mathrm{P} 2 \mathrm{Y}_{12}$ receptor by secreted ADP in dog platelets. Unlike human and murine platelets, protease-activated receptor 4 (PAR4)-activating peptide AYPGKF failed to cause dog platelet aggregation. Moreover, PAR1-activating peptide SFLLRN or co-stimulation of SFLLRN and AYPGKF failed to induce dog platelet aggregation. We conclude that ADP induces platelet aggregation through the $\mathrm{P} 2 \mathrm{Y}_{1}$ and $\mathrm{P} 2 \mathrm{Y}_{12}$ receptors in dogs. Unlike human and murine platelets, selective activation of the PAR4 receptor may be insufficient to cause platelet aggregation in dog platelets.
\end{abstract}

Keywords: Platelets; Dogs; Thrombin; Protease-activated receptors; Adenosine diphosphate

\section{Introduction}

Platelets are essential for thrombosis. Formation of a platelet thrombus is triggered by a variety of stimuli like the presence of collagen, adenosine diphosphate (ADP), thromboxane, epinephrine, and thrombin. ADP is an important platelet agonist that causes platelet aggregation via shape change, activating fibrinogen receptor, releasing granule contents, and producing thromboxane A2 mediating through its receptors $\mathrm{P} 2 \mathrm{Y}_{1}, \mathrm{P} 2 \mathrm{Y}_{12}$, and $\mathrm{P} 2 \mathrm{X} 1[15,22,33,36]$. Both the $\mathrm{P} 2 \mathrm{Y}_{1}$ and $\mathrm{P} 2 \mathrm{Y}_{12}$ receptors are essential for ADP- induced fibrinogen receptor activation and subsequent platelet aggregation in human and mouse platelets [23]. $\mathrm{P}_{2} \mathrm{Y}_{1}$ receptor stimulation increases intracellular calcium through the generation of $\mathrm{IP}_{3}$ and activation of protein kinase $\mathrm{C}$ (PKC) through the formation of diacylglycerol, following phospholipase $\mathrm{C}$ (PLC) activation [4,22]. The $\mathrm{P} 2 \mathrm{Y}_{12}$ receptor couples to $G_{i}$ and inhibits adenylyl cyclase $[16,25]$. Although the mechanism and pathway involved in ADP-induced platelet aggregation have been described in human and mouse platelets, such information remains unclear in dog platelets.

Among the platelet agonists, thrombin is considered the most important and potent one that activates platelets via proteaseactivated receptors (PARs), a class of $G$ protein-coupled receptors (GPCRs) and a glycoprotein GPIb $\alpha$ [17,31,35]. PARs couple to $G_{q}$ and $G_{i}$ and activate phospholipase $C$ that activates PKC by the generation of a secondary messenger [34] and inhibits adenylyl cyclase by secreted ADP from dense granules $[18,24,38]$ in human and mouse platelets [31]. There are three types of PAR; PAR1, PAR3, and PAR4 that are involved in thrombin-induced platelet aggregation in human and mouse [20,38,40]. Human platelets act via PAR1 [38] and PAR4, and mouse via PAR3 and PAR4 [10,20,24,39,40]. PAR1 binding provides rapid calcium influx, and platelet-platelet aggregation tends to be transient. PAR4 is associated with a slower, extended calcium influx, which is essential for the release of secondary signals necessary for complete and strong platelet 
activation $[10,11,37]$. Secreted ADP is important for platelet activation. ADP is released from dense granules after platelet activation by thrombin and stimulates $\mathrm{G}_{\mathrm{i}}$ pathways through the $\mathrm{P}_{2} \mathrm{Y}_{12}$ receptor [26], and thrombin-induced Akt phosphorylation depends on $\mathrm{G}_{\mathrm{i}}$ pathways in human and mouse platelets [27].

Thrombin receptor activating peptides (TRAPs) are peptide sequences that match tethered ligands cleaved by enzymes during thrombin-induced platelet activation [39] and cause thrombin-independent activation of PARs. Either PAR1 or PAR4 alone can cause platelet aggregation in human and mouse platelets [17]. The TRAP SFLLRN selectively activates PAR1 in human but not mouse and induces platelet aggregation and degranulation [18,38], whereas GYPGQV and GYPGKF activate human and mouse PAR4 tethered ligands, respectively [24]. GYPGKF is more effective in inducing human platelet aggregation than GYPGQV [1], while AYPGKF is a more selective and potent PAR4 activating peptide [13]. Dog platelet PARs and the pathways involved in dog platelet aggregation have not been fully elucidated but are thought to express PAR1 and PAR4 receptor subtypes as reported in humans [3].

Although these agonists and their receptors have been identified as involved in molecular events leading to platelet aggregation in human and mouse, the signaling events and mechanisms in dog platelets are still not reported. In the present study, we have characterized the signal transduction pathways of agonists that mediate dog platelet activation, information that is important in elucidating the mechanisms involved in bleeding disorders in dogs. We examined the effects of ADP, thrombin, SFFLRN, and AYPGKF in dog platelets in order to explore platelet signaling mechanisms. We show that ADP-induced platelet aggregation requires both $\mathrm{P} 2 \mathrm{Y}_{1}$ and $\mathrm{P} 2 \mathrm{Y}_{12}$ receptor activation in dog platelets. Further, thrombin causes dog platelet aggregation which is dependent on the secreted ADP causing $\mathrm{G}_{\mathrm{i}}$ stimulation. Unlike human and murine platelets, the PAR4 activating peptide AYPGKF fails to cause dog platelet aggregation. In addition, co-stimulation of PAR1 and PAR4 receptor with SFLLRN and AYPGKF is unable to cause dog platelet aggregation, suggesting the presence of an underlying mechanism for thrombin-induced platelet aggregation in dogs that is different from those in human and mouse.

\section{Materials and Methods}

\section{Materials}

Thrombin, 2-methylthio-ADP (2-MeSADP), apyrase (type V), MRS2179 (a P2Y 1 receptor antagonist [2]), prostaglandin $\mathrm{E}_{1}\left(\mathrm{PGE}_{1}\right)$, sodium citrate, and acetylsalicylic acid were purchased from Sigma (USA). Hexapeptides SFLLRN and AYPGKF were custom synthesized by Invitrogen (USA). Anti-phospho-Akt $\left(\mathrm{Ser}^{473}\right)$ and anti- $\beta$-actin antibodies were purchased from Cell Signaling Technology (USA).
Horseradish peroxidase-labeled secondary antibody was obtained from Santa Cruz Biotechnology (USA). Bisindolylmaleimide I (GF 109203X) was purchased from Calbiochem (USA). The AR-C69931MX was a gift from AstraZeneca (UK). All other reagents were reagent grade, and deionized water was used throughout.

\section{Preparation of washed dog platelets}

All animal experiments were performed in accordance with the approval obtained from the Chungbuk National University Animal Ethics Committee (approval No. CBNUA-873-15-02). Each experiment was repeated three times with blood samples from different dogs. We used blood from male and female mixed-breed dogs aged 5 to 12 years old. Blood was withdrawn from cephalic veins using $\mathrm{ACD} / 3.8 \%$ sodium citrate as an anticoagulant. Anticoagulated blood was centrifuged at $100 \times \mathrm{g}$ continuously for $10 \mathrm{~min}$ at room temperature to obtain platelet-rich-plasma (PRP). The PRP was then centrifuged at $800 \times \mathrm{g}$ for $10 \mathrm{~min}$, and obtained platelet pellet was resuspended with Tyrode's buffer ( $\mathrm{pH}$ 7.4) containing 0.05 units $/ \mathrm{mL}$ apyrase. Washed dog platelets were adjusted to a concentration of $2 \times 10^{8}$ cells $/ \mathrm{mL}$.

\section{Platelet aggregation}

The prepared platelets were allowed to rest for $30 \mathrm{~min}$ at room temperature, and aggregations were measured by using a Lumi-aggregometer (Chrono-Log, USA) at $37^{\circ} \mathrm{C}$ under stirring conditions $(900 \mathrm{r} / \mathrm{min})$. Washed platelet samples $(0.5 \mathrm{~mL})$ were stimulated with each of the different agonists for $3.5 \mathrm{~min}$, and aggregation tracings were measured.

\section{Western blotting}

Washed platelets were stimulated with thrombin for $3 \mathrm{~min}$, and the reaction was stopped by the addition of $3 \times$ sodium dodecyl sulfate (SDS) sample buffer. Before agonist stimulation, GF109203X (10 $\mu \mathrm{M})$, a PKC inhibitor, and AR-C69931MX $(100 \mathrm{nM})$, a $\mathrm{P} 2 \mathrm{Y}_{12}$ receptor antagonist [19], were added and the mixture incubated for $5 \mathrm{~min}$ at $37^{\circ} \mathrm{C}$ without stirring. Levels of phospho-Akt were determined after immunoblotting with anti-phospho-Akt $\left(\mathrm{Ser}^{473}\right)$ antibody. Platelet samples were separated via $10 \%$ SDS-polyacrylamide gel electrophoresis (PAGE) and transferred onto a polyvinylidene difluoride membrane. Immunoreactivity was detected by using a Fujifilm Luminescent Image Analyzer (LAS-3000 CH; Fujifilm, Japan).

\section{Results}

\section{ADP-induced platelet aggregation requires co-activation of both the $P 2 Y_{1}$ and $P 2 Y_{12}$ receptors in dogs}

In the present study, we investigated the role of $\mathrm{P} 2 \mathrm{Y}$ receptors in ADP-induced dog platelet aggregation. We used the stronger P2Y agonist 2-MeSADP instead of ADP [29]. As shown in Fig. 
A
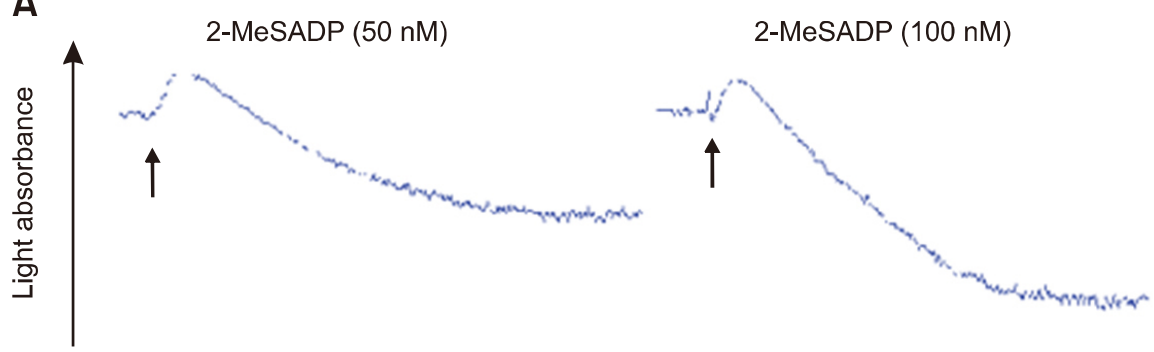

B

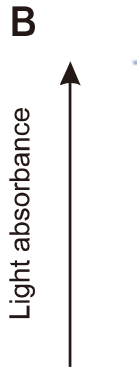

2-MeSADP (200 nM)

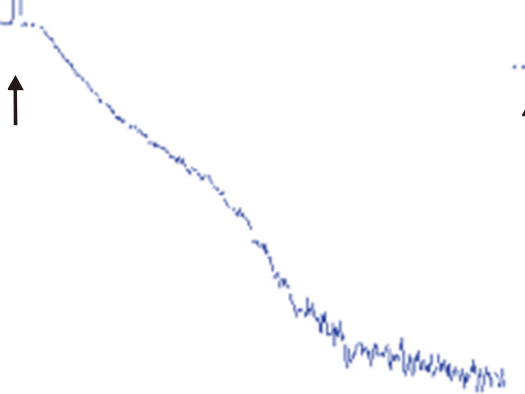

2-MeSADP + AR-C69931MX

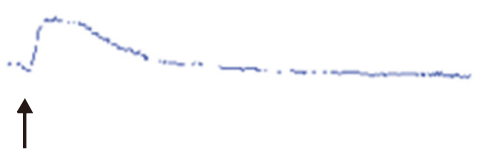

2-MeSADP (200 nM)

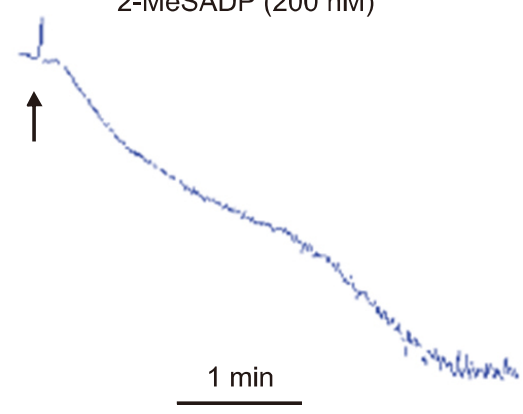

2-MeSADP + MRS2179

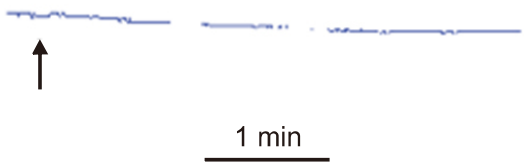

Fig. 1. 2-Methylthio-adenosine diphosphate (2-MeSADP)-induced platelet aggregation in canine platelets. (A) Washed platelets from dog were stimulated with different concentrations of 2-MeSADP for 3.5 min under stirring conditions. (B) 2-MeSADP-induced platelet aggregation was measured in washed canine platelets in the presence of $100 \mathrm{nM}$ AR-C69931MX or $100 \mu \mathrm{M}$ MRS2179. Platelet aggregation was measured by using a Lumi-aggregometer (Chrono-Log). The arrow indicates when agonist is added. Tracings are representative of three independent experiments.

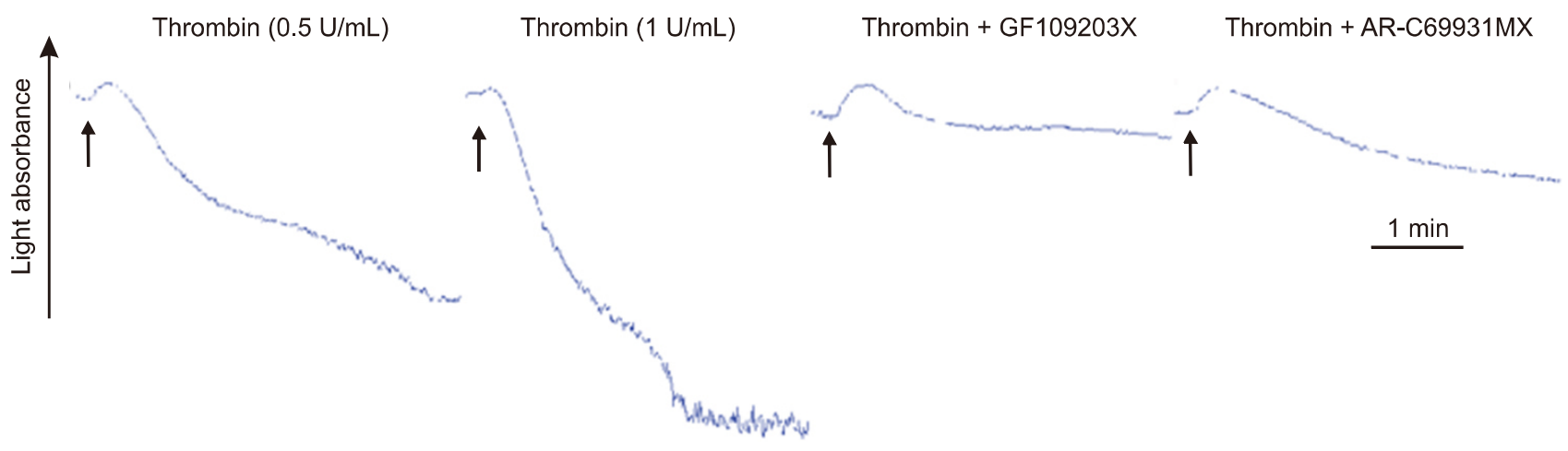

Fig. 2. The effect of secreted adenosine diphosphate on thrombin-induced platelet aggregation in canine platelets. Thrombin-induced platelet aggregation was measured in canine platelets in the presence of $10 \mu \mathrm{M}$ GF109203X or $100 \mathrm{nM}$ AR-C69931MX. The arrow indicates when agonist is added. Tracings are representative of three independent experiments.

1, stimulation of washed dog platelets with 2-MeSADP resulted in platelet aggregation in a concentration-dependent manner. Application of 2-MeSADP resulted in a shape change but failed to induce platelet aggregation in the presence of ARC69931MX. In addition, MRS2179, completely abolished platelet aggregation. These results indicate that ADP-induced platelet aggregation in the dog requires concomitant signaling from both $\mathrm{P} 2 \mathrm{Y}_{1}$ and $\mathrm{P} 2 \mathrm{Y}_{12}$ receptors, and $\mathrm{P} 2 \mathrm{Y}_{1}$ alone can produce shape change only, failing to induce platelet aggregation in the dog.

\section{Thrombin-induced dog platelet aggregation requires secreted ADP}

As shown in Fig. 2, thrombin induced dog platelet aggregation in a concentration-dependent manner. Thrombininduced platelet aggregation was significantly inhibited in the presence of PKC inhibitor GF109203X indicating an important role of $\mathrm{G}_{\mathrm{i}}$ stimulation through secretion in dog platelets. This 
result was further confirmed by significant inhibition of thrombin-induced platelet aggregation in the presence of $\mathrm{P} 2 \mathrm{Y}_{12}$ antagonist AR-C69931MX in the dog. This indicates that secreted ADP is required for thrombin-induced platelet aggregation in the dog. These results indicate that thrombin causes $\mathrm{G}_{\mathrm{i}}$ stimulation by activating the $\mathrm{P} 2 \mathrm{Y}_{12}$ receptor through secreted ADP in dog platelet aggregation.

\section{Contribution of secreted ADP and Gi pathways to thrombin-mediated Akt phosphorylation in dog platelets}

In order to confirm the contribution of $\mathrm{G}_{\mathrm{i}}$ pathways by ADP secreted in response to thrombin in dog platelets, we compared Akt phosphorylation in response to thrombin in platelets from dogs. Immunoblot analysis revealed that thrombin induced phosphorylation of Akt at $\mathrm{Ser}^{473}$ in dog platelets (Fig. 3). However, thrombin-induced Akt phosphorylation was inhibited in the presence of either GF109203X or AR-C69931MX, suggesting the contribution of $\mathrm{G}_{\mathrm{i}}$ pathways, by secreted ADP, to Akt phosphorylation in dog platelets.

\section{Selective stimulation of either PAR1 or PAR4 is insufficient to cause platelet aggregation in dogs}

As shown in Fig. 4, both the PAR1 agonist SFLLRN and the PAR4 agonist AYPGKF failed to induce platelet aggregation, even at high concentrations, indicating selective stimulation of either PAR1 or PAR4 is insufficient to cause dog platelet aggregation. Interestingly, co-stimulation by SFLLRN and AYPGKF also failed to induce platelet aggregation.

\section{Discussion}

Characterization of the platelet receptors associated with different agonists is essential for elucidating the thrombosis and

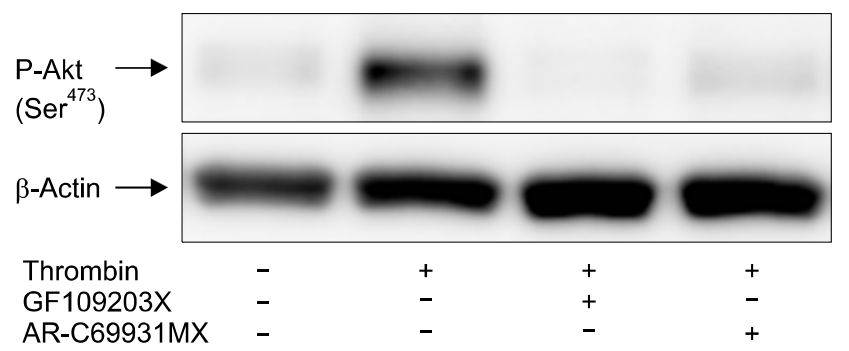

Fig. 3. Role of secreted adenosine diphosphate and Gi-coupled $\mathrm{P}_{2} \mathrm{Y}_{12}$ receptor signaling in Akt phosphorylation in response to thrombin in canine platelets. Canine platelets preincubated with $100 \mathrm{nM}$ AR-C69931MX or $10 \mu \mathrm{M}$ GF109203X were stimulated at $37^{\circ} \mathrm{C}$ for $3 \mathrm{~min}$ with thrombin ( $1 \mathrm{unit} / \mathrm{mL}$ ). Samples were separated by SDS-PAGE, transferred onto polyvinylidene difluoride membranes, and phosphorylation of Akt was measured by western blotting using an anti-phospho-Akt $\left(\mathrm{Ser}^{473}\right)$ antibody. $\beta$-Actin was used as a lane-loading control. Results are representative of three independent experiments. hemostasis mechanisms in the dog. Although the signaling pathways have been investigated deeply in human and mouse platelets, little has been reported about dog platelets. The results in earlier studies are insufficient for use in describing agonist-induced platelet activation in dogs $[3,5,12,30]$. Thus, we investigated the signaling pathways involved in dog platelet aggregation. In this study, we characterized the underlying mechanisms of platelet aggregation induced by 2-MeSADP and thrombin in dog platelets, the effect of ADP secretion on thrombin-induced platelet aggregation in dog platelets, and described AYPGKF- and SFLLRN-induced platelet aggregation in dog platelets.

It has been shown that ADP-induced platelet aggregation requires co-activation of $\mathrm{G}_{\mathrm{q}}$-coupled $\mathrm{P} 2 \mathrm{Y}_{1}$ and $\mathrm{G}_{\mathrm{i}}$-coupled $\mathrm{P} 2 \mathrm{Y}_{12}$ receptors in human and mouse platelets [6,25]. We observed that 2-MeSADP-induced platelet aggregation was inhibited by either AR-C69931MX or MRS2179, suggesting that signaling events downstream of both $\mathrm{P}_{2} \mathrm{Y}_{1}$ and $\mathrm{P} 2 \mathrm{Y}_{12}$ receptors are essential for ADP-induced platelet aggregation in dogs; moreover, neither $\mathrm{P}_{2} \mathrm{Y}_{1}$ nor $\mathrm{P} 2 \mathrm{Y}_{12}$ receptors alone are sufficient to cause platelet aggregation. Platelet shape change in the presence of AR-C69931MX but not MRS2179 in

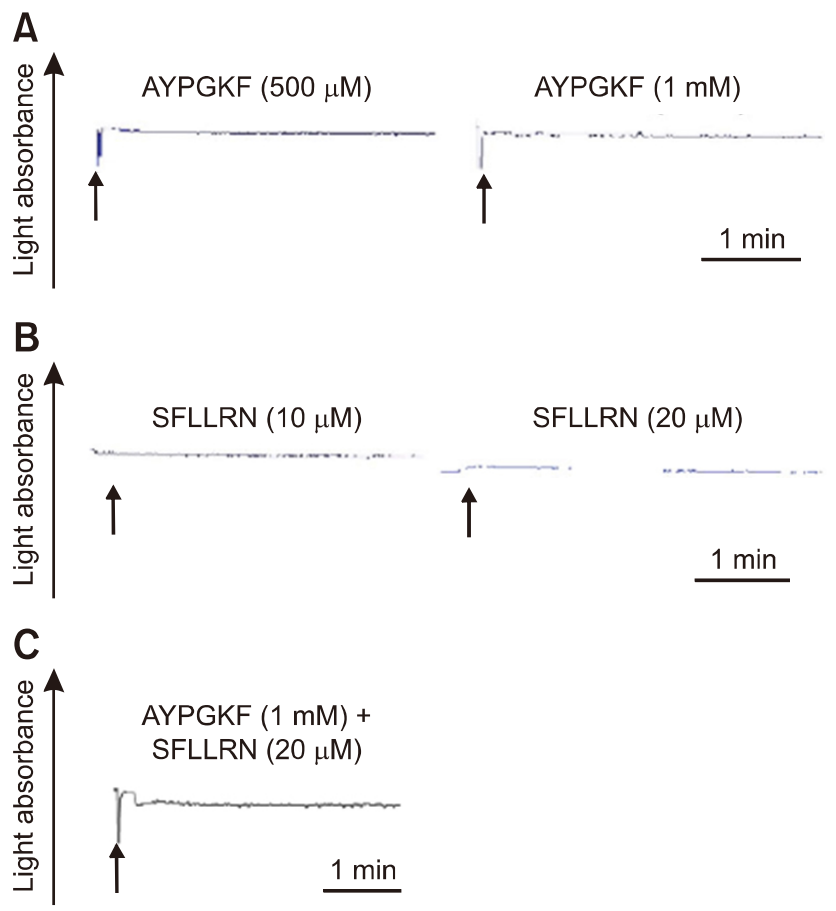

Fig. 4. AYPGKF- and SFLLRN-induced platelet aggregation in canine platelets. Washed platelets from dog were stimulated with different concentrations of the protease-activated receptor 4 (PAR4)-activating peptide AYPGKF (A), the PAR1-activating peptide SFLLRN (B), or combination of AYPGKF and SFLLRN (C) for 3.5 min under stirring conditions. The arrow indicates when agonist is added. Data are representative of three independent experiments. 
2-MeSADP-induced platelet stimulation is attributable to a shape change caused by the $G_{q}$ pathway through a P2 $Y_{1}$ receptor not by the $\mathrm{G}_{\mathrm{i}}$ pathway through a $\mathrm{P} 2 \mathrm{Y}_{12}$ receptor [6].

It has been shown that thrombin stimulates PLC $\beta$, which activates $\mathrm{PKC}$ via generation of a second messenger, causing platelet aggregation [34]. A PKC selective inhibitor can abolish $\alpha$-thrombin-induced inhibition of adenylyl cyclase [26]. Thrombin-induced platelet aggregation was inhibited in the presence of PKC inhibitor GF109203X. It has been reported that thrombin-induced platelet aggregation depends on secreted ADP, which stimulates $\mathrm{G}_{i}$ pathways through a $\mathrm{P}_{2} \mathrm{Y}_{12}$ receptor in both human and mouse platelets [7,26,35]. We observed that thrombin-induced platelet aggregation was significantly inhibited in the presence of a $\mathrm{P}_{2} \mathrm{Y}_{12}$ receptor antagonist, which is consistent with previous findings [21]. This suggests the need for secreted ADP for thrombin-stimulated platelet aggregation, which is further supported by the fact that released ADP stabilizes and enhances thrombin-induced human platelet aggregation [7,14]. In order to confirm the contribution of $G_{i}$ pathways through secreted ADP in response to thrombin in dog platelets, we compared Akt phosphorylation in response to thrombin in platelets from dogs and our immunoblot analysis showed thrombin-induced Akt phosphorylation was inhibited in the presence of GF109203X or AR-C69931MX. Thus, it appears that thrombin-induced platelet aggregation requires $\mathrm{G}_{\mathrm{i}}$ pathway stimulation through secreted ADP in dog platelets.

Thrombin is a bivalent functional agonist in which PAR1 exists in a stable complex with PAR4 [32]. In our study, we showed thrombin-induced platelet aggregation occurs in a robust manner, which assures the presence of thrombin receptors in dog platelets. When we used PAR1-activating peptide SFLLRN and the more potent PAR4 agonist AYPKGF $[13,17]$, the agonists could not induce aggregation in dog platelets even at high concentrations. It may be possible that dog platelets may have reduced affinity to bind to soluble TRAPs or TRAPs may fail to aggregate platelets to a greater extent than thrombin itself, or dog platelets may not respond to TRAPs designed from human or even dog sequences, as was predicted by some other studies $[5,12,30]$. Dog platelets failed to aggregate with either of the activating peptides $[8,9,12,28]$ suggesting the need for further study of PARs in dog blood. The study of agonist-induced platelet activation in dogs will help to describe and characterize the molecular mechanisms and functional roles of platelets in bleeding disorders of different breeds of dogs.

In summary, we conclude that, as in humans and mice, dog platelets require co-activation of both the $\mathrm{P}_{2} \mathrm{Y}_{1}$ and $\mathrm{P}_{2} \mathrm{Y}_{12}$ receptors for ADP-induced platelet aggregation. Thrombin requires secreted ADP to induce platelet aggregation by $\mathrm{G}_{\mathrm{i}}$ stimulation via $\mathrm{P} 2 \mathrm{Y}_{12}$ receptor activation in dog platelets, and selective stimulation of either PAR1 or PAR4 is insufficient to cause platelet aggregation in dogs. We propose the need for further study of PARs to elucidate the signaling mechanism of thrombin-induced platelet aggregation in dogs at the receptor level.

\section{Acknowledgments}

This work was supported by the National Research Foundation of Korea (NRF) Grant of the Korean government (NRF-2016R1D1A1B01010310), the Global Research and Development Center (GRDC) Program through the NRF funded by the Ministry of Education, Science and Technology (2017K1A4A3014959), and the research grant of the Chungbuk National University in 2015.

\section{Conflict of Interest}

The authors declare no conflicts of interest.

\section{References}

1. Andersen H, Greenberg DL, Fujikawa K, Xu W, Chung DW, Davie EW. Protease-activated receptor 1 is the primary mediator of thrombin-stimulated platelet procoagulant activity. Proc Natl Acad Sci U S A 1999, 96, 11189-11193.

2. Baurand A, Raboisson P, Freund M, Léon C, Cazenave JP, Bourguignon JJ, Gachet C. Inhibition of platelet function by administration of MRS2179, a $\mathrm{P}_{2} \mathrm{Y}_{1}$ receptor antagonist. Eur J Pharmacol 2001, 412, 213-221.

3. Boudreaux MK, Catalfamo JL, Klok M. Calciumdiacylglycerol guanine nucleotide exchange factor I gene mutations associated with loss of function in canine platelets. Transl Res 2007, 150, 81-92.

4. Brass LF, Manning DR, Cichowski K, Abrams CS. Signaling through $\mathrm{G}$ proteins in platelets: to the integrins and beyond. Thromb Haemost 1997, 78, 581-589.

5. Catalfamo JL, Andersen TT, Fenton JW 2nd. [Thrombin receptor-activating peptides unlike thrombin are insufficient for platelet activation in most species]. Thromb Haemost 1993, 69, 1195. German.

6. Cattaneo M. $\mathrm{P} 2 \mathrm{Y}_{12}$ receptor antagonists: a rapidly expanding group of antiplatelet agents. Eur Heart J 2006, 27, 1010-1012.

7. Cattaneo M, Canciani MT, Lecchi A, Kinlough-Rathbone RL, Packham MA, Mannucci PM, Mustard JF. Released adenosine diphosphate stabilizes thrombin-induced human platelet aggregates. Blood 1990, 75, 1081-1086.

8. Connolly TM, Condra C, Feng DM, Cook JJ, Stranieri MT, Reilly CF, Nutt RF, Gould RJ. Species variability in platelet and other cellular responsiveness to thrombin receptorderived peptides. Thromb Haemost 1994, 72, 627-633.

9. Cook NS, Zerwes HG, Tapparelli C, Powling M, Singh J, Mettemich R, Hagenbach A. Platelet aggregation and fibrinogen binding in human, rhesus monkey, guinea-pig, hamster and rat blood: activation by ADP and a thrombin receptor peptide and inhibition by glycoprotein IIb/IIIa antagonists. Thromb Haemost 1993, 70, 531-539.

10. Covic L, Gresser AL, Kuliopulos A. Biphasic kinetics of 
activation and signaling for PAR1 and PAR4 thrombin receptors in platelets. Biochemistry 2000, 39, 5458-5467.

11. Covic L, Singh C, Smith H, Kuliopulos A. Role of the PAR4 thrombin receptor in stabilizing platelet-platelet aggregates as revealed by a patient with Hermansky-Pudlak syndrome. Thromb Haemost 2002, 87, 722-727.

12. Derian CK, Santulli RJ, Tomko KA, Haertlein BJ, Andrade-Gordon P. Species differences in platelet responses to thrombin and SFLLRN. receptor-mediated calcium mobilization and aggregation, and regulation by protein kinases. Thromb Res 1995, 78, 505-519.

13. Faruqi TR, Weiss EJ, Shapiro MJ, Huang W, Coughlin SR. Structure-function analysis of protease-activated receptor 4 tethered ligand peptides. Determinants of specificity and utility in assays of receptor function. J Biol Chem 2000, 275, 19728-19734.

14. Gachet C, Hechler B, Léon C, Vial C, Leray C, Ohlmann P, Cazenave JP. Activation of ADP receptors and platelet function. Thromb Haemost 1997, 78, 271-275.

15. Gachet C, Hechler B, Léon C, Vial C, Ohlmann P, Cazenave JP. Purinergic receptors on blood platelets. Platelets 1996, 7, 261-267.

16. Garcia A, Shankar H, Murugappan S, Kim S, Kunapuli SP. Regulation and functional consequences of ADP receptormediated ERK2 activation in platelets. Biochem J 2007, 404, 299-308.

17. Henriksen RA, Hanks VK. PAR-4 agonist AYPGKF stimulates thromboxane production by human platelets. Arterioscler Thromb Vasc Biol 2002, 22, 861-866.

18. Hung DT, Vu TH, Nelken NA, Coughlin SR. Thrombininduced events in non-platelet cells are mediated by the unique proteolytic mechanism established for the cloned platelet thrombin receptor. J Cell Biol 1992, 116, 827-832.

19. Ingall AH, Dixon J, Bailey A, Coombs ME, Cox D, McInally JI, Hunt SF, Kindon ND, Teobald BJ, Willis PA, Humphries RG, Leff P, Clegg JA, Smith JA, Tomlinson W. Antagonists of the platelet $\mathrm{P}_{2 T}$ receptor: a novel approach to antithrombotic therapy. J Med Chem 1999, 42, 213-220.

20. Ishihara H, Connolly AJ, Zeng D, Kahn ML, Zheng YW, Timmons C, Tram T, Coughlin SR. Protease-activated receptor 3 is a second thrombin receptor in humans. Nature 1997, 386, 502-506.

21. Jantzen HM, Milstone DS, Gousset L, Conley PB, Mortensen RM. Impaired activation of murine platelets lacking $\mathrm{G \alpha}_{\mathrm{i} 2}$. J Clin Invest 2001, 108, 477-483.

22. Jin J, Daniel JL, Kunapuli SP. Molecular basis for ADP-induced platelet activation. II. The P2Y1 receptor mediates ADP-induced intracellular calcium mobilization and shape change in platelets. J Biol Chem 1998, 273, 2030-2034.

23. Jin J, Kunapuli SP. Coactivation of two different $G$ protein-coupled receptors is essential for ADP-induced platelet aggregation. Proc Natl Acad Sci U S A 1998, 95, 8070-8074.

24. Kahn ML, Zheng YW, Huang W, Bigomia V, Zeng D, Moff S, Farese RV Jr, Tam C, Coughlin SR. A dual thrombin receptor system for platelet activation. Nature 1998, 394, 690-694.

25. Kahner BN, Shankar H, Murugappan S, Prasad GL,
Kunapuli SP. Nucleotide receptor signaling in platelets. J Thromb Haemost 2006, 4, 2317-2326.

26. Kim S, Foster C, Lecchi A, Quinton TM, Prosser DM, Jin J, Cattaneo M, Kunapuli SP. Protease-activated receptors 1 and 4 do not stimulate $G_{i}$ signaling pathways in the absence of secreted ADP and cause human platelet aggregation independently of $\mathrm{G}_{\mathrm{i}}$ signaling. Blood 2002, 99, 3629-3636.

27. Kim S, Jin J, Kunapuli SP. Akt activation in platelets depends on $\mathrm{G}_{\mathrm{i}}$ signaling pathways. J Biol Chem 2004, 279, 4186-4195.

28. Kinlough-Rathbone RL, Rand ML, Packham MA. Rabbit and rat platelets do not respond to thrombin receptor peptides that activate human platelets. Blood 1993, 82, 103-106.

29. Kunapuli SP, Dorsam RT, Kim S, Quinton TM. Platelet purinergic receptors. Curr Opin Pharmacol 2003, 3, 175-180.

30. Lau LF, Pumiglia K, Côté YP, Feinstein MB. Thrombinreceptor agonist peptides, in contrast to thrombin itself, are not full agonists for activation and signal transduction in human platelets in the absence of platelet-derived secondary mediators. Biochem J 1994, 303, 391-400.

31. Leger AJ, Covic L, Kuliopulos A. Protease-activated receptors in cardiovascular diseases. Circulation 2006, 114, 1070-1077.

32. Leger AJ, Jacques SL, Badar J, Kaneider NC, Derian CK, Andrade-Gordon P, Covic L, Kuliopulos A. Blocking the protease-activated receptor 1-4 heterodimer in plateletmediated thrombosis. Circulation 2006, 113, 1244-1254.

33. Mills DC. ADP receptors on platelets. Thromb Haemost 1996, 76, 835-856.

34. Nonne C, Lenain N, Hechler B, Mangin P, Cazenave JP, Gachet C, Lanza F. Importance of platelet phospholipase $\mathrm{C} \gamma 2$ signaling in arterial thrombosis as a function of lesion severity. Arterioscler Thromb Vasc Biol 2005, 25, 1293-1298.

35. Nylander S, Mattsson C, Lindahl TL. Characterisation of species differences in the platelet ADP and thrombin response. Thromb Res 2006, 117, 543-549.

36. Takasaki J, Kamohara M, Saito T, Matsumoto M, Matsumoto S, Ohishi T, Soga T, Matsushime H, Furuichi K. Molecular cloning of the platelet $\mathrm{P}^{2} \mathrm{~T}_{\mathrm{AC}} \mathrm{ADP}$ receptor: pharmacological comparison with another ADP receptor, the $\mathrm{P}_{2} \mathrm{Y}_{1}$ receptor. Mol Pharmacol 2001, 60, 432-439.

37. Trumel C, Payrastre B, Plantavid M, Hechler B, Viala C, Presek P, Martinson EA, Cazenave JP, Chap H, Gachet C. A key role of adenosine diphosphate in the irreversible platelet aggregation induced by the PAR1-activating peptide through the late activation of phosphoinositide 3-kinase. Blood 1999, 94, 4156-4165.

38. Vu TK, Hung DT, Wheaton VI, Coughlin SR. Molecular cloning of a functional thrombin receptor reveals a novel proteolytic mechanism of receptor activation. Cell 1991, 64, 1057-1068.

39. Weiss DJ, Wardrop KJ. Schalm's Veterinary Hematology. John Wiley \& Sons, New York, 2011.

40. Xu WF, Andersen H, Whitmore TE, Presnell SR, Yee DP, Ching A, Gilbert T, Davie EW, Foster DC. Cloning and characterization of human protease-activated receptor 4 . Proc Natl Acad Sci U S A 1998, 95, 6642-6646. 